\title{
Investigation of Teachers' Attitudes Towards Sports in Turkey
}

\author{
Mehmet Şakir Salar ${ }^{1}{ }^{*}$, Hulusi ALP ${ }^{2}$
}

${ }_{1}{ }^{2}$ Suleyman Demirel University, Turkey

\begin{abstract}
Article History:
Received: 27 March 2021

Accepted: 20 April 2021

Published: 26 April 2021

Keywords:

Sport; Attitude; Teacher

Abstract

This research was conducted to examine the Attitudes of Teachers working in public schools towards Sports in terms of Different Variables. The data of the research were obtained from 403 teachers working in Aydın during the 2020-2021 academic year. As the data collection tool, "Attitude Scale towards Sports" made by Halil Evren Şentürk (2012) was used. Descriptive statistics and nonparametric tests were used to analyze the data. Mann Whitney U-test was used for comparisons of two groups, and Kruskal Wallis $\mathrm{H}$ was used for comparing more than two groups. The Cronbach's Alpha coefficient of the scale was found to be 0.97 . As a result of the research, a statistically significant difference was found as a result of the analysis made between the sub-dimensions of the attitude towards sports in the variables of the teachers' Gender, Education and Branch $(p<0.05)$. In the gender variable, it was concluded that the Attitudes of Female Teachers towards Sports were higher than male teachers in all sub-dimensions of the scale. When the Educational Status Variable is examined, it is seen that in the dimension of Interest in Sports, Graduate Teachers' Attitudes towards Sports are higher than Undergraduate teachers. In the Active Sports dimension, it is concluded that the Graduate Teachers' Attitude towards Sports scores are higher than the Undergraduate Teachers. It was concluded that there was no statistically significant difference between the sub-dimensions of age, marital status, education level and attitude towards sports ( $p>0.05)$.
\end{abstract}

\section{How To Cite:}

Salar, M. S, \& ALP, H. (2021). Investigation of Teachers' Attitudes Towards Sports in Aydin Province. Indonesian Journal of Sport Management, 1(1), 20-30. https://doi.org/10.31949/ijsm.v1i1.967

Corresponding author: Mehmet Şakir Salar, Suleyman Demirel University, Turkey Email: ekim1778@gmail.com 


\section{INTRODUCTION}

Sport is defined as "an activity that involves physical exertion and skill in which an individual or team competes against another or others for fun" (Oxford English Dict, 2017). Although sport is as old as the history of mankind, it has been seen as an action that develops by affecting civilizations and affects individuals both personally and socially (Kalfa, 2 019). The primary goal of sport is to promote physical activity, improve health, performance, psychosocial development, and motor skills (Hold et al., 2017). In addition, doing sports provides a chance to be a part of a community, to acquire new social environments, to establish social norms and attitudes, to create an identity and to develop a sense of belonging (Hassmen et al., 2000). As physical activity is carried out in a more planned and programmed way around the world, the role of sport in society has become more important over time, not only for the individual but also for public health (Malm et al., 2019). Absence of physical activity increases the risk of major noncommunicable diseases, shortens life expectancy, and significantly increases the cost of healthcare expenditures (Lee, 2012).

During childhood and adolescence, physical education classes offered in schools can be ideal environments to encourage and direct the implementation of physical and sports activities and active physical activity (Standage et al., 2005). Physical education and sports aim to provide children and adolescents with basic movement skills knowledge and active attitude for lifelong physical activity (Hills et al., 2015). Regular participation in physical activity is important to maintaining the benefits of the activity. Active individuals enjoy a high level of fitness and we had lower health risks than inactive people (Lopez Sanches et al., 2016). Due to the sedentary lifestyle of people, the promotion of physical activity and sports has become one of the most important goals of schools in most developed societies. Societies are aware that physical exercise and sports play a very important role in the protection and improvement of health in humans (Janssen, 2007). Each individual has their own ideas and attitudes towards sports, which is accepted as an integral part of life (Tükel, 2018). Attitudes are not congenital, they are learned over time, show a certain continuity, regulate the relationship between the individual and the object, help people to interpret their environment, and affect the individual's behavior internally (Tavşancıl, 2002; Pepe et al., 2011; Turan et al., 2018; Dalbudak et al, 2016; Dalbudak and Yiğit 2019; Binbaşıoğlu and Tuna, 2014; Akıncı, 2020a).

The teacher is one of the main supporters of the implementation of physical activities, so their figures are very important for students to increase their regular physical activity levels (Gil Arias et al., 2017). Teachers' attitudes towards sports are very important for sports to become widespread. Determining teachers' attitudes towards sports; Situations such as active sports, their perspective to sports, and their approach to sports habits have an important role in increasing the number of individuals engaged in active sports (Ünver et al., 2019). Studies have determined that teachers have positive psychological aspects such as increasing the intrinsic motivation of students in physical education classes and will allow the development and reinforcement of physical activity-related behaviors (Sanches Oliva et al., 2017). During the school period, positive attitudes towards sports can be formed in this period as the attitudes, self-efficacy, social skills, personality traits of the individuals on certain subjects are shaped and become a lifestyle (Balyan et al., 2012; Akıncl, 
2020b). The situation of individuals who are interested in sports, who make sports a part of their life, who strive to do sports at an elite level in the future, and who do sports at an elite level, reflects their attitudes towards sports (Şentürk, 2015).

With the explanation of the basic concepts of the research, it was made in order to determine the attitudes of the teachers in different branches who were selected as the target group in the study and working in the province of Aydın towards sports.

\section{METHOD}

In the research, scanning model, which is one of the non-experimental quantitative research types, was used. In the non-experimental research model, the researcher does not make any intervention. The existing situation is being examined within the scope of the research (Şata, 2020). The universe of the study was composed of teachers working in Aydin province, Nazilli district. The sample consisted of 403 teachers who voluntarily agreed to participate in the study. The data of the study and the scale forms of 403 teachers who make up the sample group were prepared on Google form and filled out on a voluntary basis.

As a data collection tool, the Attitudes Towards Sports Scale (ATSS) was used. In the reliability analysis performed to determine the internal consistency of the scale, its total value was found to be 0.972. Interest in Sports Dimension was found as 0.972, Living with Sports Dimension as 0.983 and Active Sports Dimension as 0.954 . In addition, there is no negative relationship between any item in the scale and the total correlation. The scale is rated between 1-5 in 5-point Likert type (Şentürk, 2012). A total of 403 people were reached, and 323 questionnaires were found suitable for analysis after 80 questionnaires that were found to be incomplete or inaccurate were removed. Descriptive statistics and parametric tests were used in the analysis of the data. The normality test was applied to the data set in order to determine which of the parametric tests is appropriate. Since the significance level was less than 0.05 according to the Kolmogorov-Smirnova test, it was seen that the data did not show normal distribution and non-parametric tests were found suitable for analysis. Mann Whitney-U test was used to compare two independent variables, and Kruskal Wallis $\mathrm{H}$ test was used to compare more than two variables. Tamhane's T2, one of the Post-Hoc tests, was used to detect the difference between multiple variables.

\section{RESULT AND DISCUSSION}

The highest variables in their own category are respectively $27.9 \%(n=90)$ in the age variable of teachers, teachers in the age range of 22-30, female teachers with $57.3 \%(n=185)$ in the gender variable, $71.8 \%$ in marital status $(n=232)$ married teachers, graduates with $86.1 \%(n=278)$ in the education variable, $44.3 \%(n=143)$ secondary school at the level of education they worked in, and $11.1 \%(n=36)$ physical education and sports teachers in the branch variable.

Table 1 shows descriptive statistics regarding the demographic characteristics of teachers. 
Table 1. Distribution of teachers' demographic data

\begin{tabular}{|c|c|c|c|}
\hline Variables & Characteristics & $\mathrm{f}$ & $\%$ \\
\hline \multirow{5}{*}{ Age } & $22-30$ & 90 & 27,9 \\
\hline & $31-35$ & 78 & 24,1 \\
\hline & $36-40$ & 62 & 19,2 \\
\hline & $41-45$ & 42 & 13,0 \\
\hline & 4660 & 51 & 15,8 \\
\hline \multirow{2}{*}{ Gender } & Female & 185 & 57,3 \\
\hline & Male & 138 & 42,7 \\
\hline \multirow{2}{*}{ Marital Status } & Married & 232 & 71,8 \\
\hline & Single & 91 & 28,2 \\
\hline \multirow{2}{*}{ Education Status } & License & 278 & 86,1 \\
\hline & Graduate & 45 & 13,9 \\
\hline \multirow{3}{*}{$\begin{array}{l}\text { Education Level at } \\
\text { Work }\end{array}$} & Primary School & 45 & 13,9 \\
\hline & Middle School & 143 & 44,3 \\
\hline & High school & 135 & 41,8 \\
\hline \multirow{13}{*}{ Branch } & $\begin{array}{l}\text { Physical Education and Sports } \\
\text { Teacher }\end{array}$ & 36 & 11,1 \\
\hline & Foreign Language Teachers & 35 & 10,8 \\
\hline & $\begin{array}{l}\text { Chemistry, Physics, Biology and } \\
\text { Science Teacher }\end{array}$ & 27 & 8,4 \\
\hline & Turkish and Literature Teacher & 30 & 9,3 \\
\hline & $\begin{array}{l}\text { History, Geography and Social } \\
\text { Studies Teacher }\end{array}$ & 29 & 9,0 \\
\hline & Music and Visual Arts Teacher & 14 & 4,3 \\
\hline & Preschool and Classroom Teacher & 31 & 9,6 \\
\hline & Special Education Teacher & 30 & 9,3 \\
\hline & $\begin{array}{l}\text { Religious Culture and Ethics } \\
\text { Teacher }\end{array}$ & 19 & 5,9 \\
\hline & PDR and Philosophy Teacher & 18 & 5,6 \\
\hline & Mathematics Teacher & 31 & 9,6 \\
\hline & $\begin{array}{l}\text { Information Technologies, } \\
\text { Vocational Courses and Technology } \\
\text { Design Teacher }\end{array}$ & 23 & 7,1 \\
\hline & Total & 323 & 100 \\
\hline
\end{tabular}

Table 2. Comparison of teachers' attitudes

\begin{tabular}{|c|c|c|c|c|c|c|c|}
\hline $\begin{array}{l}\text { Scale Sub- } \\
\text { Dimensions }\end{array}$ & Gender & $\mathrm{N}$ & $\begin{array}{l}\text { Mean } \\
\text { Rank }\end{array}$ & $\begin{array}{l}\text { Sum of } \\
\text { Rank }\end{array}$ & $\mathrm{U}$ & $\mathrm{z}$ & $\mathrm{p}$ \\
\hline $\begin{array}{l}\text { Interest in } \\
\text { Sports }\end{array}$ & $\begin{array}{c}\text { Famele } \\
\text { Male }\end{array}$ & $\begin{array}{l}185 \\
138\end{array}$ & $\begin{array}{l}186,20 \\
129,55\end{array}$ & $\begin{array}{l}34447,50 \\
17878,50\end{array}$ & 8287,500 & $-5,398$ & ,000 \\
\hline $\begin{array}{l}\text { Living with } \\
\text { Sports }\end{array}$ & $\begin{array}{c}\text { Famele } \\
\text { Male }\end{array}$ & $\begin{array}{l}185 \\
138\end{array}$ & $\begin{array}{l}180,72 \\
136,91\end{array}$ & $\begin{array}{l}33432,50 \\
18893,50\end{array}$ & 9302,500 & $-4,184$ & ,000 \\
\hline $\begin{array}{l}\text { Playing Active } \\
\text { Sports }\end{array}$ & $\begin{array}{c}\text { Famele } \\
\text { Male }\end{array}$ & $\begin{array}{l}185 \\
138\end{array}$ & $\begin{array}{l}175,61 \\
143,75\end{array}$ & $\begin{array}{c}32488,00 \\
19838,00\end{array}$ & 10247,000 & $-3,041$ & ,002 \\
\hline
\end{tabular}

When Table 2 is examined, it was seen that there is a statistically significant difference between the teachers' attitudes towards sports and the gender variable, in all sub-dimensions of the scale, according to the Mann Whitney $U$ test results ( $p$ $<0.05)$. 
Table 3.Comparison of teachers' attitudes towards sports according to marital status variable

\begin{tabular}{lccccccc}
\multicolumn{1}{c}{$\begin{array}{c}\text { Scale Sub- } \\
\text { Dimensions }\end{array}$} & $\begin{array}{c}\text { Marital } \\
\text { Status }\end{array}$ & N & $\begin{array}{c}\text { Mean } \\
\text { Rank }\end{array}$ & $\begin{array}{c}\text { Sum of } \\
\text { Rank }\end{array}$ & U & z & p \\
Interest in & Married & 232 & 164,34 & 38127,50 & 10012,500 &,- 721 &, 471 \\
Sports & Single & 91 & 156,03 & 14198,50 & & & \\
Living with & Married & 232 & 161,62 & 37495,50 & 10467,500 &,- 118 &, 906 \\
Sports & Single & 91 & 162,97 & 14830,50 & & \\
Playing Active & Married & 232 & 160,03 & 37126,00 & \multirow{2}{*}{10098,000} &,- 608 &, 543 \\
Sports & Single & 91 & 167,03 & 15200,00 & & \\
\hline
\end{tabular}

When Table 3 is examined, it has been observed that there is no statistically significant difference in all sub-dimensions of the scale between the teachers' attitudes towards sports and the marital status variable according to the Mann Whitney U test results ( $p>0.05)$.

Table 4. Comparison of teachers' attitudes towards sports according to educational level variable

\begin{tabular}{lccccccc}
\multicolumn{1}{c}{$\begin{array}{c}\text { Scale Sub- } \\
\text { Dimensions }\end{array}$} & $\begin{array}{c}\text { Education } \\
\text { Status }\end{array}$ & $\mathrm{N}$ & $\begin{array}{c}\text { Mean } \\
\text { Rank }\end{array}$ & $\begin{array}{c}\text { Sum of } \\
\text { Rank }\end{array}$ & $\mathrm{U}$ & $\mathrm{z}$ & $\mathrm{p}$ \\
\hline Interest in & License & 278 & 157,04 & 43657,00 & 4876,000 & - & \multirow{2}{*}{, 375} \\
Sports & Graduate & 45 & 192,64 & 8669,00 & & \\
Living with & License & 278 & 159,77 & 44415,00 & 5634,000 & 1,072 &, 284 \\
Sports & Graduate & 45 & 175,80 & 7911,00 & & - &, 021 \\
Playing Active & License & 278 & 157,20 & 43700,50 & 4919,500 & 2,304 &, 0218 \\
Sports & Graduate & 45 & 191,68 & 8625,50 & & & \\
\hline
\end{tabular}

When Table 4 is examined, it was seen that there is a statistically significant difference between the teachers' attitudes towards sports and the educational status variable in the sub-dimensions of interest in sports and active sports according to the Mann Whitney $U$ test results $(\mathrm{p}<0.05)$.

Table 5. Comparison of teachers' attitudes towards sports by age variable

\begin{tabular}{|c|c|c|c|c|c|c|}
\hline Scale Sub-Dimensions & Gender & $\mathrm{N}$ & Mean Rank & $X^{2}$ & $\mathrm{df}$ & $\mathrm{p}$ \\
\hline \multirow{5}{*}{ Interest in Sports } & $22-30$ & 90 & 157,86 & \multirow{5}{*}{1,628} & \multirow{5}{*}{4} & \multirow{5}{*}{,804 } \\
\hline & $31-35$ & 78 & 160,12 & & & \\
\hline & $36-40$ & 62 & 157,38 & & & \\
\hline & $41-45$ & 42 & 177,93 & & & \\
\hline & $46-60$ & 51 & 164,69 & & & \\
\hline \multirow{5}{*}{ Living with Sports } & $22-30$ & 90 & 160,19 & \multirow{5}{*}{1,306} & \multirow{5}{*}{4} & \multirow{5}{*}{,860 } \\
\hline & $31-35$ & 78 & 165,96 & & & \\
\hline & $36-40$ & 62 & 158,69 & & & \\
\hline & $41-45$ & 42 & 173,52 & & & \\
\hline & $46-60$ & 51 & 153,67 & & & \\
\hline \multirow{5}{*}{ Playing Active Sports } & $22-30$ & 90 & 158,60 & \multirow{5}{*}{2,132} & \multirow{5}{*}{4} & \multirow{5}{*}{,711 } \\
\hline & $31-35$ & 78 & 172,89 & & & \\
\hline & $36-40$ & 62 & 165,90 & & & \\
\hline & $41-45$ & 42 & 156,40 & & & \\
\hline & $46-60$ & 51 & 151,21 & & & \\
\hline
\end{tabular}


When Table 5 is examined, according to the Kruskal Wallis $\mathrm{H}$ test results, it was observed that there was no statistically significant difference between the teachers' attitudes towards sports and the age variable in all sub-dimensions of the scale $(p>0.05)$.

Table 6. Comparison of teachers' attitudes towards sports according to the variable of education level they work in.

\begin{tabular}{|c|c|c|c|c|c|c|}
\hline $\begin{array}{c}\text { Scale Sub- } \\
\text { Dimensions }\end{array}$ & $\begin{array}{c}\text { Education } \\
\text { Level at Work }\end{array}$ & $\mathrm{N}$ & Mean Rank & $X^{2}$ & $\mathrm{df}$ & $\mathrm{p}$ \\
\hline \multirow{3}{*}{ Interest in Sports } & $\begin{array}{l}\text { Primary } \\
\text { School }\end{array}$ & 45 & 182,34 & \multirow{3}{*}{2,901} & \multirow{3}{*}{2} & \multirow{3}{*}{,235 } \\
\hline & Middle School & 143 & 162,21 & & & \\
\hline & High school & 135 & 155,00 & & & \\
\hline \multirow{3}{*}{ Living with Sports } & $\begin{array}{l}\text { Primary } \\
\text { School }\end{array}$ & 45 & 183,73 & \multirow{3}{*}{3,607} & \multirow{3}{*}{2} & \multirow{3}{*}{ 165 } \\
\hline & Middle School & 143 & 163,20 & & & \\
\hline & High school & 135 & 153,49 & & & \\
\hline \multirow{3}{*}{$\begin{array}{l}\text { Playing Active } \\
\text { Sports }\end{array}$} & $\begin{array}{l}\text { Primary } \\
\text { School }\end{array}$ & 45 & 172,28 & \multirow{3}{*}{,907 } & \multirow{3}{*}{2} & \multirow{3}{*}{,636 } \\
\hline & Middle School & 143 & 157,52 & & & \\
\hline & High school & 135 & 163,32 & & & \\
\hline
\end{tabular}

When Table 6 is examined, according to the Kruskal Wallis $\mathrm{H}$ test results, it was seen that there was no statistically significant difference between the teachers' attitudes towards doing sports and the educational level variable they work with in all sub-dimensions of the scale ( $p>0.05)$.

When Table 7 is examined, a statistically significant difference was observed between the teachers' attitudes towards sports and the branch variable in all subdimensions of the scale $(\mathrm{p}<0.05)$. Post-Hoc test was conducted to determine which groups caused the difference. In the sub-dimension of interest in sports, the attitude scores of Physical Education and Sports Teachers are Foreign Language Teachers (German and English), Chemistry, Physics, Biology and Science, Turkish and Literature, History, Geography and Social, Religion and Ethics, PDR and Philosophy, Mathematics and Information Technologies, Vocational Courses and Technology Design teachers' attitude scores. In the sub-dimension of Life with Sports, Physical Education and Sports Teachers' attitude scores are Foreign Language Teachers (German and English), Chemistry, Physics, Biology and Science, Turkish and Literature, Religion and Moral Knowledge, PDR and Philosophy, Mathematics and Information Technologies, Profession It is higher than the attitude scores of the courses and Technology Design teachers. In the Active Sports sub-dimension, Physical Education and Sports Teachers' attitude scores are higher than all other teachers except Music and Visual Arts teachers. 
Table 7. Comparison of teachers' attitudes towards sports according to the branch variable

\begin{tabular}{|c|c|c|c|c|c|c|c|}
\hline $\begin{array}{c}\text { Scale } \\
\text { Sub- } \\
\text { Dimen } \\
\text { si- } \\
\text { ons }\end{array}$ & Branş & $\mathrm{N}$ & $\begin{array}{cc}\text { Mean } & X \\
\text { Rank } & 2\end{array}$ & df & $\mathrm{p}$ & & $\begin{array}{l}\text { Post- } \\
\text { Hoc }\end{array}$ \\
\hline \multirow{12}{*}{$\begin{array}{l}\text { Interes } \\
\text { t in } \\
\text { Sports }\end{array}$} & 1Physical Education and Sports Teacher & 36 & 250,22 & \multirow{12}{*}{58,238} & \multirow{12}{*}{11} & \multirow{12}{*}{00} & \multirow{12}{*}{$\begin{array}{l}1>2 \\
1>3 \\
1>4 \\
1>5 \\
1>9 \\
1>10 \\
1>11 \\
1>12\end{array}$} \\
\hline & ${ }^{2}$ Foreign Language Teachers & 35 & 126,23 & & & & \\
\hline & $\begin{array}{l}{ }^{3} \text { Chemistry, Physics, Biology and Science } \\
\text { Teacher }\end{array}$ & 27 & 134,06 & & & & \\
\hline & ${ }^{4}$ Turkish and Literature Teacher & 30 & 164,93 & & & & \\
\hline & $\begin{array}{l}{ }^{5} \text { History, Geography and Social Studies } \\
\text { Teacher }\end{array}$ & 29 & 160,45 & & & & \\
\hline & ${ }^{6}$ Music and Visual Arts Teacher & 14 & 172,43 & & & & \\
\hline & ${ }^{7}$ Preschool and Classroom Teacher & 31 & 180,53 & & & & \\
\hline & ${ }^{8}$ Special Education Teacher & 30 & 191,28 & & & & \\
\hline & ${ }^{9}$ Religious Culture and Ethics Teacher & 19 & 107,00 & & & & \\
\hline & 10PDR and Philosophy Teacher & 18 & 111,44 & & & & \\
\hline & 11Mathematics Teacher & 31 & 137,40 & & & & \\
\hline & $\begin{array}{l}\text { 12Information Technologies, Vocational } \\
\text { Courses and Technology Design Teacher }\end{array}$ & 23 & 157,91 & & & & \\
\hline \multirow{12}{*}{$\begin{array}{l}\text { Living } \\
\text { with } \\
\text { Sports }\end{array}$} & ${ }^{1}$ Physical Education and Sports Teacher & 36 & 236,36 & \multirow{12}{*}{50,639} & \multirow{12}{*}{11} & \multirow{12}{*}{$\begin{array}{l}00 \\
0\end{array}$} & \multirow{12}{*}{$\begin{array}{l}1>2 \\
1>3 \\
1>4 \\
1>9 \\
1>10 \\
1>11 \\
1>12\end{array}$} \\
\hline & ${ }^{2}$ Foreign Language Teachers & 35 & 139,93 & & & & \\
\hline & $\begin{array}{l}{ }^{3} \text { Chemistry, Physics, Biology and Science } \\
\text { Teacher }\end{array}$ & 27 & 149,35 & & & & \\
\hline & ${ }^{4}$ Turkish and Literature Teacher & 30 & 148,55 & & & & \\
\hline & $\begin{array}{l}{ }^{5} \text { History, Geography and Social Studies } \\
\text { Teacher }\end{array}$ & 29 & 173,29 & & & & \\
\hline & ${ }^{6}$ Music and Visual Arts Teacher & 14 & 175,39 & & & & \\
\hline & ${ }^{7}$ Preschool and Classroom Teacher & 31 & 177,58 & & & & \\
\hline & ${ }^{8}$ Special Education Teacher & 30 & 199,63 & & & & \\
\hline & ${ }^{9}$ Religious Culture and Ethics Teacher & 19 & 93,39 & & & & \\
\hline & 10PDR and Philosophy Teacher & 18 & 112,33 & & & & \\
\hline & ${ }^{11}$ Mathematics Teacher & 31 & 145,19 & & & & \\
\hline & $\begin{array}{l}\text { 12Information Technologies, Vocational } \\
\text { Courses and Technology Design Teacher }\end{array}$ & 23 & 137,30 & & & & \\
\hline \multirow{12}{*}{$\begin{array}{l}\text { Playing } \\
\text { Active } \\
\text { Sports }\end{array}$} & ${ }^{1}$ Physical Education and Sports Teacher & 36 & 258,71 & \multirow{12}{*}{56,007} & \multirow{12}{*}{11} & \multirow{12}{*}{$\begin{array}{l}00 \\
0\end{array}$} & \multirow{12}{*}{$\begin{array}{l}1>2 \\
1>3 \\
1>4 \\
1>5 \\
1>7 \\
1>8 \\
1>9 \\
1>10 \\
1>11 \\
1>12\end{array}$} \\
\hline & ${ }^{2}$ Foreign Language Teachers & 35 & 150,19 & & & & \\
\hline & $\begin{array}{l}{ }^{3} \text { Chemistry, Physics, Biology and Science } \\
\text { Teacher }\end{array}$ & 27 & 156,39 & & & & \\
\hline & 4Turkish and Literature Teacher & 30 & 150,93 & & & & \\
\hline & $\begin{array}{l}{ }^{5} \text { History, Geography and Social Studies } \\
\text { Teacher }\end{array}$ & 29 & 151,55 & & & & \\
\hline & ${ }^{6}$ Music and Visual Arts Teacher & 14 & 160,21 & & & & \\
\hline & ${ }^{7}$ Preschool and Classroom Teacher & 31 & 172,42 & & & & \\
\hline & ${ }^{8}$ Special Education Teacher & 30 & 173,10 & & & & \\
\hline & ${ }^{9}$ Religious Culture and Ethics Teacher & 19 & 105,66 & & & & \\
\hline & ${ }^{10} \mathrm{PDR}$ and Philosophy Teacher & 18 & 108,47 & & & & \\
\hline & 11Mathematics Teacher & 31 & 139,10 & & & & \\
\hline & $\begin{array}{l}{ }^{12} \text { Information Technologies, Vocational } \\
\text { Courses and Technology Design Teacher }\end{array}$ & 23 & 154,67 & & & & \\
\hline
\end{tabular}

In this study, teachers' attitudes towards doing sports; The way it differs according to gender, age, marital status, educational status, level of work and branch 
was examined. When the attitude scores of the teachers participating in the study are examined according to the gender variable, it is seen that there is a significant difference in all sub-dimensions of the scale $(\mathrm{p}<0.05)$. It has been observed that female teachers tend to do sports more than male teachers. The reason for this may have been effective in women's tendency to do more sports in order to lose weight and remain weak. Considering the literature studies conducted, there are studies that are similar and not similar to the research in terms of the results obtained. Atalay et al. (2015) found that the attitude towards sports is higher in favor of women according to the gender variable, and it is similar to the result of the study. Üner et al. (2019), Tomik et al. (2012) in Poland, it was found that male participants showed a higher attitude towards sports than female participants. Göksel et al. (2017) found no significant difference according to gender in the study. The result of this study is not similar to the result of the study. The reason for this can be considered as a result of being influenced by factors such as place of residence, age and living habits, although the two studies show similarities in terms of variables.

There is no significant difference between the participants' attitudes towards sports in terms of age variable ( $p>0.05)$. The lack of a meaningful difference between the age variable has increased the experience, experience and perspective of people with age, their level of enjoyment of life and the desire to live healthy, and the awareness of the problems brought by a sedentary life to human life with the benefits of technology in today's modern societies, and the participation of people in sports and sports organizations. It is thought to increase (Uğurlu, 2012). When the previous studies in the literature are examined in terms of their results (Varol et al., 2017; Atalay et al., 2015; Koçak, 2014), some studies show similar results with the study done, while some studies show that Kangalgil et al. (2006) found that there is a significant difference in terms of age in their study, and a significant difference in terms of the age variable in the study by Göksel and Caz (2016).

It was found that there was no significant difference between the attitude towards sports and the marital status variable ( $p>0.05)$. In the study conducted by Togo and Öztürk (2019), it was found that there was no difference in terms of age and attitude towards sports. Amount of meat. (2020) found a significant difference in his research. Considering that the life standards of married individuals are more planned and that single individuals tend to more different social activities, it can be thought that the reason for the difference is.

There is a significant difference between the attitude towards sports and education variable $(\mathrm{p}<0.05)$. In the dimension of interest in sports and active sports, it is seen that postgraduate teachers' attitude scores towards sports are higher than undergraduate teachers ( $p>0.05)$. Although there is no significant difference in the dimension of living with sports, attitude scores of graduate teachers are relatively higher than teachers at undergraduate level.

It has been determined that there is no significant difference between the type of school they work in and their attitude towards sports. There was a statistically significant difference between the teachers' attitudes towards sports and the branch variable in all sub-dimensions of the attitude towards sports scale $(\mathrm{p}<0.05)$. In all subgroups, it is seen that physical education and sports teachers' attitude scores are higher than other branches. 


\section{CONCLUSION}

It can be said that teachers' attitudes towards sports are also very important in guiding students to sports. Tournaments can be organized to improve teachers' attitudes towards sports. School administrations and teachers can hold seminars at schools in the presence of guidance counselors to raise awareness of sports in parents. By including in-school and out-of-school sports activities, teachers can participate in sports activities. By applying this research on a larger sample group, the results can be made more generalizable.

\section{ACKNOWLEDGEMENT}

We would like to thank all those who have supported the completion of this research.

\section{REFERENCES}

Akıncı, A.Y. (2020). A Research on the relationship between academic self-efficacy of prospective physical education and sports teachers and their attitudes towards the turkish education history course. Journal of Education and Learning, 9(4), pp. 131139, 2020a.

Akıncı, A.Y. (2020). The Relationship between teacher candidates' self-efficacy and attitudes of sports history. International Education Studies, 13(7), pp.105-112, 2020b.

Atalay, A., Akbulut, A., Yücel, A., Göral, K., and Korkmaz, M. (2015). Analysis of the attitudes of student-atheletes playing in the universities volleyball 2nd league in turkey towards sports. J. Appl. Environ. Biol. Sci., 5(4)1-6.

Balyan, M., Balyan, K. Y., ve Kiremitçi, O. (2012). The effects of different sports activities on the social skills and self-efficacy levels of primary school 2nd grade students' attitude towards physical education lesson. Selcuk University Journal of Physical Education and Sports Science,14(2), 196-201.

Binbaşığlu, H., and Tuna, H. (2014). University students' attitudes towards their leisure time: a research for vocational school students in the eastern anatolia region. Journal of Academic Approaches. Cilt 5, s2.

Dalbudak İ, and Yiğit Ş.M (2019). Hearing Imparied students' attitudes towards physical education and sports. Journal of Education and Training Studies, Vol. 7, No. 9; 55-60.

Dalbudak, I.,Gürkan, A.C., Yigit, S.M., Kargun, M., Hazar, G., and Dorak, F. (2016). Investigating visually disabled students' attitudes about physical education and sport. International Journal of Environmental and Science Education, Vol. 11, No. 16, pp:9437-9447.

Gil-Arias, A., Harvey, S., Cárceles, A., Práxedes, A. ve Del Villar, F. (2017). The effect of a mixed TGfU-sports training unit on student motivation in physical education. PloS, 12 (6).

Göksel, A. G., and Caz, C.. (2016). Examination of anatolian high school students' attitudes towards physical education lesson. Marmara University Journal of Sports Sciences, 1(1), 3-10.

Göksel, A. G., Caz, C.., and İkizler, H. (2017). Comparison of students' attitudes towards sports in different departments: The case of Marmara University. Journal of Sports and Performance Researches, 8(2). 
Hassmén P, Koivula N, Uutela A. Physical exercise and psychological well-being: a population study in Finland. Prev Med. 2000 Jan;30(1):17-25.

Hills AP, Dengel DR, Lubans DR. Supporting public health priorities: recommendations for physical education and physical activity promotion in schools. Prog Cardiovasc Dis. 2015 Jan-Feb;57(4): 368-74.

Holt, N. L., Neely, K. C., Slater, L. G., Camiré, M., Côté, J., Fraser-Thomas, J., MacDonald, D., Strachan, L., \& Tamminen, K. A. (2017). A grounded theory of positive youth development through sport based on results from a qualitative metastudy. International Review of Sport and Exercise Psychology, 10(1), 1-49.

Janssen I. (2007). Physical activity guidelines for children and teens. Appl Physiol Nutr Metab, 32: pp. $109-121$.

Kalfa, M. (2019). Attitudes of dentistry students towards sports. Spormeter Journal of Physical Education and Sport Sciences, 17(1), 165-181.

Koçak, F. (2014). University students' attitudes towards sports: a scale development study. 12(1),59-60.

Lee IM, Shiroma EJ, Lobelo F, Puska P, Blair SN, Katzmarzyk PT(2012). Lancet physical activity series working group. effect of physical inactivity on major noncommunicable diseases worldwide: an analysis of burden of disease and life expectancy. Lancet, 21;380(9838):219-29.

López Sánchez, GF, González Víllora, S. ve Díaz Suárez, A. (2016). Usual level of physical activity among children and adolescents in the Murcia Region (Spain). Springer Plus, 5 (1), 386.

Malm, C., Jakobsson, J. ve Isaksson, A. (2019). Physical activity and sport-real health benefits: A Review with Insights into Swedish Public Health. Sport (Basel, Ísviçre), 7 (5), 127.

Oxford English Dictionary. Sport. Oxford English Dict. Online. 2017 [Cited May 12, 2017]. Available at: https://en.oxforddictionaries.com/definition/sport

Pepe, O., Taşkıran. C., Pepe, K., Çoksevim, B. (2011). Attitude of first grade teachers of primary education schools related to physical education and sport lessons ovidius university annals. Series Physical Education and Sport / Science, Movement and Health Vol. 11, issue 2; pp:221-228.

Sánchez-Oliva, D., Pulido-González, JJ, Leo, FM, González-Ponce, I., \& García-Calvo, T. (2017). Effects of an intervention with teachers in the context of physical education: SelfDetermination Theory approach. PloS, 12 (12).

Standage, M., Duda, JL, \& Ntoumanis, N. (2005). A self-determination theory test in school physical education. British Journal of Educational Psychology, 75 (3), 411-433.

Şata, M. (2020). Quantitative research methods. E. Oğuz (Ed.), Research methods in education (77-97). Ankara: Educational Book.

Şentürk, H. E. (2012). Sportive Attitude Scale: its development, validity and reliability. CBÜ Journal of Physical Education and Sport Sciences, 7 (2), 8-18.

Tavşancıl, E. (2002). Measuring attitudes and data analysis with SPSS. Nobel Publishing, Ankara. 5. Edition, p. 224. 
Togo, O. T., and Öztürk, A. (2019) Examining the attitudes of employees participating in sports organizations towards sports: the example of the corporate league. Journal of Sports and Performance Research, 11 (1), 55-64.

Tomik, R., Olex-Zarychta, D., and Mynarski, W. (2012). Social values of sport participation and their significance for youth attitudes towards physical education and sport. Studies in Physical Culture and Tourism, 19 (2), 99-104.

Turan, M.B., Usuflu, O., Koç, K., Karaoğlu, B., and Ulucan H. (2018). Investigation of human rights attitudes and uniqueness levels in sports of professional football players. Gaziantep University Journal of Sport Sciences Vol: 3, Issue: 4, pp: 1-18.

Amount, Ö. F., Nacar, E., and Gacar, A. (2020). Investigation of alienation levels in sports of enforcement officers. Munzur University Journal of Social Sciences (MÜSBID), 9 (1), 6878.

Tükel, Y. (2018). Evaluation of athletes playing table tennis as a sports recreation activity towards sports according to gender and marital status. Sportive, 1(1), 12-18.

Uğurlu, F. (2012). Investigation of university students' level of participation in sports activities and their social adaptation and communication skills (Adlyaman province example). Gaziantep University, Institute of health sciences, department of physical education and sports, Master's Thesis, 5-81.

Ünver, G., Ersan, K.ve Kocaman, H. (2019). Examination of teachers' attitudes towards sports in different branches. Journal of Physical Education and Sport Sciences, 13 (1), 38-50.

Varol, R., Varol, S., and Türkmen, M. (2017). Determining the attitudes of students studying at bartın university towards sports. International Journal ofCultural and Social Studies (UKSAD), 3 (2), 316-329

\section{Copyright holder:}

C(2021) Mehmet Şakir Salar, Hulusi ALP

First publication right:

Indonesian Journal of Sport Management

This article is licensed under: 